\title{
Real-Time Reverse Transcription Polymerase Chain Reaction for Rapid Detection of Transmissible Gastroenteritis Virus
}

\section{Ramesh Vemulapalli}

\begin{abstract}
Transmissible gastroenteritis (TGE) is a highly contagious disease of pigs caused by the TGE virus (TGEV). Rapid detection of the virus in the affected pigs' feces is critical for controlling the disease outbreaks. The real-time RT-PCR assay described in this chapter can quickly detect the presence of TGEV in fecal samples with high sensitivity and specificity.
\end{abstract}

Key words TGE virus, Real-time RT-PCR, Feces, Pigs

\section{Introduction}

Transmissible gastroenteritis (TGE) is a highly contagious, acute viral disease of pigs [1]. TGE can affect pigs of all ages, but the disease severity and mortality rate are high in piglets under 2 weeks of age. The causative agent is TGE virus (TGEV), a coronavirus that primarily infects and replicates in the epithelial cells of pig intestines. Affected animals shed the virus in their feces. The disease transmission occurs primarily via fecal-oral route [2]. During an outbreak, rapid detection of TGEV in feces is very useful for implementing the disease management practices in a timely manner. Any TGEV-specific diagnostic assay must be able to differentiate it from porcine respiratory coronavirus (PRCV), a natural mutant of TGEV with truncated spike protein and altered cell tropism towards respiratory epithelial cells [3]. PRCV mostly causes mild or subclinical respiratory disease. However, in some PRCV-infected pigs, the virus can be shed in the feces [4]. Realtime PCR-based assays are well suited for rapid, specific, and sensitive detection of viruses such as TGEV. The real-time RT-PCR assay described here is based on amplification of a conserved region of the spike protein gene of TGEV strains and detection of 
the amplified products using a TaqMan probe [5]. The assay, along with the RNA extraction method described here, can be established in any molecular diagnostic laboratory for detection of TGEV in pig fecal samples [6-8].

\section{Materials}

\subsection{RNA Extraction}

1. TRIzol LS Reagent (Invitrogen).

2. RNeasy Mini Kit (Qiagen).

3. Chloroform.

4. Ethanol, 70 and $96-100 \%$.

5. DNase/RNase-free distilled water.

6. Feces samples from suspected pigs.

\subsection{Real-Time \\ RT-PCR}

1. OneStep RT-PCR Kit (Qiagen).

2. RNasin Ribonuclease Inhibitor (Promega) or equivalent.

3. $25 \mathrm{mM} \mathrm{MgCl}_{2}$ solution for PCR (Sigma-Aldrich) or equivalent.

4. DNase/RNase-free distilled water.

5. $10 \mu \mathrm{M}$ Forward primer, 5'-TCTGCTGAAGGTGCTATTAT ATGC-3'.

6. $10 \mu \mathrm{M}$ Reverse primer, $5^{\prime}$-CCACAATTTGCCTCTGAATTAG AAG-3'.

7. $2.5 \mu \mathrm{M}$ Probe $5^{\prime}$-(FAM)YAAGGGCTCACCACCTACTACCA CCA(BHQ1)-3'(FAM，6-carboxyfluorescein; BHQ1, black hole quencher 1; Eurofins MWG Operon).

8. Real-time PCR machine, such as Smart Cycler II (Cepheid), 7300 Real-Time PCR System (Applied Biosystems), or equivalent.

9. PCR reaction tubes suitable for the real-time PCR machine platform.

\section{Methods}

Preventing contamination of samples and reagents with nucleic acids and nucleases is critical to obtaining accurate and reproducible results with any PCR-based diagnostic assay. It is recommended that the nucleic acid extraction, preparation of master mix, and real-time PCR amplification are performed in three physically separated areas. Each of these areas should have separate set of laboratory instruments and supplies that are to be used only in their 
assigned location [9]. Including a positive extraction control and a negative extraction control along with each batch of clinical samples is recommended to monitor the efficiency of RNA extraction and potential cross contamination of the samples [9].

\subsection{RNA Extraction}

PCR inhibitors are often co-extracted with nucleic acids from fecal samples. In our experience, RNA extracted from pig fecal samples using the following method is suitable for TGEV detection using the real-time RT-PCR assay. Other extraction methods that produce PCR inhibitor-free RNA can also be used (see Note 1). The presence of PCR inhibitors in the extracted can be monitored by using an internal control (see Note 2).

1. Prepare a $20 \%(\mathrm{w} / \mathrm{v})$ suspension of feces in DNase/RNasefree distilled water. Feces in liquid form can be used directly.

2. Transfer $250 \mu \mathrm{l}$ of the fecal suspension into a $1.5 \mathrm{ml}$ microcentrifuge tube.

3. Add $750 \mu \mathrm{l}$ of TRIzol LS reagent, briefly vortex the tube for $10 \mathrm{~s}$, and incubate at room temperature for $5 \mathrm{~min}$.

4. Add $200 \mu \mathrm{l}$ of chloroform to the tube. Vortex the tube for $5 \mathrm{~s}$ and incubate at room temperature for $3 \mathrm{~min}$.

5. Centrifuge the tube at $12,000 \times g$ for $10 \mathrm{~min}$.

6. Transfer $600 \mu \mathrm{l}$ of the top aqueous phase to a new $1.5 \mathrm{ml}$ microcentrifuge tube containing $600 \mu \mathrm{l}$ of $70 \%$ ethanol and mix by inverting $4-5$ times.

7. Transfer $700 \mu \mathrm{l}$ of the mix to an RNeasy spin column and centrifuge at $8000 \times g$ for $30 \mathrm{~s}$.

8. Transfer the spin column to a new collection tube, and add the remaining mix from step 6 . Centrifuge at $8000 \times g$ for $30 \mathrm{~s}$.

9. Place the spin column into a new collection tube. Add $700 \mu \mathrm{l}$ of RWl buffer to the spin column and centrifuge at $8000 \times g$ for $30 \mathrm{~s}$.

10. Place the spin column into a new collection tube. Add $500 \mu \mathrm{l}$ of RPE buffer to the spin column and centrifuge at $8000 \times g$ for $30 \mathrm{~s}$ ( see Note 3).

11. Repeat step $\mathbf{1 0}$ for a second wash of the spin column with RPE buffer.

12. Place the spin column into a new collection tube and centrifuge at $10,000 \times \mathrm{g}$ for $1 \mathrm{~min}$ to dry the membrane of the column.

13. Place the spin column in a $1.5 \mathrm{ml}$ microcentrifuge tube and add $30 \mu \mathrm{l}$ of DNase/RNase-free water to the column. Incubate at room temperature for $1 \mathrm{~min}$.

14. Centrifuge at $10,000 \times g$ for $1 \mathrm{~min}$. 


\subsection{Real-Time RT-PCR}

15. Discard the spin column and store the eluted RNA at $4{ }^{\circ} \mathrm{C}$ if it is used in the real-time RT-PCR assay within $12 \mathrm{~h}$ or at $-20^{\circ} \mathrm{C}$ if it is used after $12 \mathrm{~h}$ ( see Note 4$)$.

1. Turn on the real-time PCR machine. Follow the software directions of the machine manufacturer to confirm that the FAM signal data will be gathered during the amplification. Program the thermal cycle and data collection conditions according to Table 1.

2. Prepare a master mix sufficient for the intended number of samples in a sterile $1.5 \mathrm{ml}$ microcentrifuge tube according to Table 2 . Add at least a no-template control (NTC) and a positive amplification control (PAC) to the number required reactions.

3 . Close the cap of the microcentrifuge tube. Vortex and centrifuge the tube briefly.

4. Aliquot $20 \mu \mathrm{l}$ of the master mix into each PCR reaction tube.

Table 1

Thermal cycling conditions

\begin{tabular}{llll}
\hline Step & & Temperature $\left({ }^{\circ} \mathbf{C}\right)$ & Time \\
\hline $\begin{array}{l}\text { 1. Reverse transcription } \\
\begin{array}{l}\text { 2. Heat inactivation of reverse transcriptase and activation of Taq DNA } \\
\text { polymerase }\end{array}\end{array}$ & 50 & $30 \mathrm{~min}$ \\
\hline $\begin{array}{l}\text { 3. Amplification and detection } \\
(45 \text { cycles })\end{array}$ & Denaturation & 95 & $15 \mathrm{~min}$ \\
& Annealing and data collection & 56 & $15 \mathrm{~s}$ \\
& Extension & 72 & $30 \mathrm{~s}$ \\
\hline
\end{tabular}

Table 2

Master mix components

\begin{tabular}{lll}
\hline Reagent & Volume per reaction $(\boldsymbol{\mu l})$ & Final concentration \\
\hline RNase-free water & 6.2 & - \\
\hline $5 \times$ Qiagen OneStep RT-PCR buffer & 5.0 & $1 \times$ \\
\hline $10 \mathrm{mM}$ dNTPs & 0.8 & $0.2 \mathrm{mM}$ \\
\hline $10 \mu \mathrm{M}$ Forward primer & 1.0 & $0.4 \mu \mathrm{M}$ \\
\hline $10 \mu \mathrm{M}$ Reverse primer & 3.0 & $1.2 \mu \mathrm{M}$ \\
\hline $2.5 \mu \mathrm{M}$ Probe & 1.5 & $0.15 \mu \mathrm{M}$ \\
\hline Ribonuclease inhibitor $(13 \mathrm{U} / \mu \mathrm{l})$ & 1.0 & $13 \mathrm{U} / \mathrm{reaction}$ \\
\hline $25 \mathrm{mM} \mathrm{MgCl}_{2}$ & 0.5 & $0.5 \mathrm{mM}$ \\
\hline Qiagen OneStep RT-PCR enzyme mix & 1.0 & - \\
\hline
\end{tabular}


5. Add $5 \mu \mathrm{l}$ of the extracted sample RNA. Add $5 \mu$ l of DNase/ RNase-free water to the NTC tube. Add $5 \mu$ l of RNA extracted from TGEV to the PAC tube.

6. Centrifuge the PCR tubes briefly.

7. Insert the PCR tubes into the real-time PCR machine and start the thermal cycling program.

8. At the completion of the amplification program, examine the amplification curves and the threshold cycles $(\mathrm{Ct})$ of the reactions. The NTC reaction and any other negative control reactions should not generate a $\mathrm{Ct}$ value. The PAC reaction and any other expected positive reactions should generate a $\mathrm{Ct}$ value as expected based on the template RNA concentration.

4 Notes

1. Magnetic bead-based manual or high-throughput RNA extraction methods (e.g., MagMax Viral RNA Isolation Kit, Life Technologies) are used in our laboratory to extract TGEV and other viral RNA from pig fecal samples.

2. Xeno RNA (Life Technologies) can be used as internal RNA control to monitor the presence of PCR inhibitors and efficiency of RNA extraction.

3. Buffer RPE of the RNeasy Kit is supplied as a concentrate. Follow the manufacturer's direction to prepare the buffer by adding the appropriate volume of $100 \%$ ethanol.

4. For long-term storage, it is recommended that the extracted viral RNA be kept at $-80{ }^{\circ} \mathrm{C}$.

\section{References}

1. Garwes DJ (1988) Transmissible gastroenteritis. Vet Rec 122:462-463

2. Saif LJ, van Cott JL, Brim TA (1994) Immunity to transmissible gastroenteritis virus and porcine respiratory coronavirus infections in swine. Vet Immunol Immunopathol 43:89-97

3. Rasschaert D, Duarte M, Laude H (1990) Porcine respiratory coronavirus differs from transmissible gastroenteritis virus by a few genomic deletions. J Gen Virol 71:2599-2607

4. Costantini V, Lewis P, Alsop J, Templeton C et al (2004) Respiratory and fecal shedding of porcine respiratory coronavirus (PRCV) in sentinel weaned pigs and sequence of the partial S-gene of the PRCV isolates. Arch Virol 149:957-974

5. Vemulapalli R, Gulani J, Santrich C (2009) A real-time TaqMan ${ }^{\circledR}$ RT-PCR assay with an internal amplification control for rapid detection of transmissible gastroenteritis virus in swine fecal samples. J Virol Methods 162:231-235

6. Huang Y, Harding JCS (2014) Attempted experimental reproduction of porcine periweaning-failure-to-thrive syndrome using tissue homogenates. PLoS One 9:e90065

7. Ojkic D, Hazlett M, Fairles J, Marom A et al (2015) The first case of porcine epidemic diarrhea in Canada. Can Vet J 56:149-152

8. Wang X, Ren W, Nie Y, Cheng L et al (2013) A novel watery diarrhea caused by the co-infection of neonatal piglets with Clostridium perfringens type A and Escherichia coli (K88, 987P). Vet J 197:812-816

9. Kessler HH, Raggam RB (2012) Quality assurance and quality control in the routine molecular diagnostic laboratory for infectious diseases. Clin Chem Lab Med 50:1153-1159 